December 2011

\title{
The State and Future of Genocide Studies and Prevention: An Overview and Analysis of Some Key Issues
}

Samuel Totten

Follow this and additional works at: https://digitalcommons.usf.edu/gsp

\section{Recommended Citation}

Totten, Samuel (2011) "The State and Future of Genocide Studies and Prevention: An Overview and Analysis of Some Key Issues," Genocide Studies and Prevention: An International Journal: Vol. 6: Iss. 3: Article 4.

Available at: https://digitalcommons.usf.edu/gsp/vol6/iss3/4

This Articles is brought to you for free and open access by the Open Access Journals at Digital Commons @ University of South Florida. It has been accepted for inclusion in Genocide Studies and Prevention: An International Journal by an authorized editor of Digital Commons @ University of South Florida. For more information, please contact digitalcommons@usf.edu. 


\title{
The State and Future of Genocide Studies and Prevention: An Overview and Analysis of Some Key Issues ${ }^{1}$
}

\author{
Samuel Totten \\ University of Arkansas
}

In addition to providing a succinct history of the field of genocide studies, this article examines such issues as the critical need to address the toughest barriers to the prevention of and intervention against genocide (e.g., realpolitik, the lack of political will, and the reform of the UN Security Council, including the make-up and operation of the Permanent Five members [Great Britain, US, France, Russia, and China]); whether the Crimes Against Humanity Initiative will make a real difference vis-à-vis the prevention of and intervention against genocide; the critical need for the field to be more inclusive by welcoming and nurturing a strong working relationship with international relations and peace studies scholars; the need for genocide scholars to more closely monitor "hot spots" (areas where crimes against humanity and genocide are likely to erupt or have already erupted); and the activist/non-activist divide in the field of genocide studies.

Key words: history of the field, prevention, intervention, UN Security Council, Permanent Five, Crimes Against Humanity Initiative, peace studies, monitoring hot spots, activists

While genocide is the intent to destroy in whole or in part a particular group as such, the stark reality is that individual human beings suffer the torment, cruelty, and brutality meted out during the genocidal period. While individual members of the group are frequently killed in horrific ways, survivors often live out the rest of their existences on earth bereft in about every way imaginable. Undoubtedly, it is my human rights background and various experiences (including incidents and situations that I have witnessed during my stints in Africa) that have driven me to keep the individual at the forefront of my mind as I delve deeper into the maw of genocide.

Over the past eight years I have spent an ever-increasing amount of time in Africa-the Nuba Mountains in Sudan and refugee camps in Chad, conducting research into the government of Sudan's genocidal actions against the people of the Nuba Mountains in the late 1980s and early 1990s and Sudan's genocidal actions against the black Africans in Darfur, respectively-and in doing so, I have seen the results of atrocity crimes up close. It changes one forever, as it should. In my case, it redoubled my dedication to focusing on the welfare of targeted groups and the individuals who comprise them. What has been most evident during the course of my research into the government of Sudan's propensity for mass violence is that when serious human rights violations are allowed to go unchecked and perpetrators are allowed to continue to perpetrate atrocities unabated, the seeds of future crimes against humanity and/or genocide are likely being sown. For me, this underscores

Samuel Totten, "The State and Future of Genocide Studies and Prevention: An Overview and Analysis of Some Key Issues." Genocide Studies and Prevention 6, 3 (December 2011): 211230. (C) 2011 Genocide Studies and Prevention. doi:10.3138/gsp.6.3.211 
the fact that as soon as there is evidence that serious human rights violations are about to be perpetrated, or are underway, it is imperative that they be halted immediately. It is unconscionable to ignore them, and it is nonsensical to wait to see if they are going to eventuate in crimes against humanity, ethnic cleansing, and/or genocide. Ideally, at the first signs of serious conflict between groups, efforts should be made to ameliorate them through the good offices of the United Nations, nongovernmental organizations (NGOs), and specialists in conflict resolution. Yes, the world is huge and rife with problems, but nothing short of ameliorating conflict and stanching serious human rights violations early on is going to prevent genocide. ${ }^{2}$ To date, far too many genocide scholars, intergovernmental officials, and leaders of individual states have been content to play the waiting game before setting into motion serious attempts to ameliorate such conflicts.

After presenting an overview of the genesis and evolution of the field of genocide studies, I will limit my comments to five issues: (1) three major impediments to the prevention and intervention of genocide (realpolitik, lack of political will, and the composition, operation, and power of the Permanent Five [P5] of the UN Security Council); (2) the critical need to bring other disciplines into the field of genocide studies to help develop efficacious means of prevention and intervention; (3) the Crimes Against Humanity Initiative; (4) the value of genocide scholars working in areas of potential and actual conflict; and (5) the scholar/activist divide.

\section{An Overview of the Field of Genocide Studies}

Before 1980, very few individuals-with the exception of international law experts analyzing the strengths and weaknesses of the UN Convention on the Prevention and Punishment of the Crime of Genocide (UNCG) and journalists covering such tragedies as the Bangladesh Genocide (1971) or the closing off of Cambodia by the Khmer Rouge (1975-1979)—thought about, let alone wrote about, genocide as a broad, general issue (as opposed to individual cases, such as the Armenian Genocide, the Holocaust, the Bangladesh Genocide). If that sounds like hyperbole, one should search through the works on genocide-books and refereed journal articles-published before 1980, or, for that matter, before 1990 .

The names of those who laid the groundwork for the development of the field are now well known. Above all, of course, was Raphael Lemkin, the Polish jurist who was forced into exile by the rise of the Nazis. He coined the term "genocide" and fought tirelessly for the establishment of the UNCG. Among those who followed in his footsteps and virtually created the field of genocide studies are illustrious names such as Leo Kuper, Irving Louis Horowitz, Israel W. Charny, and Helen Fein. Without their pioneering efforts and the efforts of the scholars who followed shortly thereafter, it is probable that the field of genocide studies would never have developed, or at least not as early as it did. That too may sound like hyperbole, but had they not individually and sometimes collectively organized the first conferences dedicated to the subject of genocide, presented papers at conferences hosted by their respective disciplines or universities, written the first books, developed the first research tools, and created the first institutes, there certainly would have been no foundation for second-, third-, and fourth-generation scholars to conveniently step onto, as they now can and do, and proceed apace as if genocide studies had existed forever.

Not only did Kuper, a political scientist (University of California, Los Angeles), write two key texts-Genocide: Its Political Use in the Twentieth Century and The 
Prevention of Genocide ${ }^{3}$ — but he also co-founded International Alert Against Genocide and Massacres in 1985 with Martin Ennals. If Kuper had lived longer (he passed away in 1994), he would have likely been at the forefront, with Charny, of developing and implementing a slew of innovative projects with the aim of forming a rock-solid foundation on which to build the new field of genocide studies.

Charny, a psychologist at Tel Aviv University, founded the Institute on the Holocaust and Genocide in 1979 with Shamai Davidson and Elie Wiesel. In 1982 he organized in Tel Aviv the first large-scale conference on genocide. From that point forward, Charny devised numerous innovations in an effort to build a foundation and then solidify the field. He founded and edited a newsletter, The Internet on the Holocaust and Genocide (1985); established a bibliographic series entitled Genocide: A Critical Bibliographic Review, first published in 1988; co-founded (with Helen Fein, Robert Melson, and Roger Smith) the International Association of Genocide Scholars (IAGS) in 1994; created and co-edited the first encyclopedia of genocide in 1999; cofounded (with the IAGS and the Zoryan Institute) Genocide Studies and Prevention: An International Journal in 2005; and, most recently, developed Genocide Prevention Now: A Holocaust and Genocide Review on the Internet for All People (2010). Throughout, he conducted research into various facets of genocide, including that which drives humans to commit mass murder. ${ }^{4}$

Fein, a sociologist, served for many years as the Executive Director of one of the earliest scholarly organizations focusing on genocide, the New York City-based Institute for the Study of Genocide (ISG), which has over the years produced an informative newsletter (ISG Newsletter) that contains reports on ongoing atrocity crimes as well as overviews of research by scholars in the field. ISG has also hosted a number of colloquia on a wide array of issues. Not to be overlooked is the fact that for the past thirty years she has continued to produce thought-provoking and timely research into an array of genocide-related issues.

In addition to his own research on genocide, Horowitz, a sociologist and founder of Transaction Publishers, was one of the first publishers to earnestly publish works on genocide. To date, Transaction's Series on Genocide has published works by Israel W. Charny, Richard Hovannisian, Ben Kiernan, and Samuel Totten, among others, including the scores of scholars who have contributed to Genocide: A Critical Bibliographic Review.

While there are others who contributed to the growth of the field and were innovators in their own right, the aforementioned scholars are the ones who truly led the pack. If not for them, it is hard to imagine the field of genocide studies being as robust as it is today.

When I entered the field of genocide studies in 1986 there were, literally, no more than just over a dozen scholars worldwide focusing on genocide-that is, on genocide theory, the prevention of and intervention against genocide, and/or comparative genocide-and a couple of dozen or so who focused on individual cases of genocide other than the Holocaust. The first group was made up of the previously mentioned individuals (Kuper, Charny, Horowitz, and Fein) as well as Roger Smith, Herb Hirsch, Barbara Harff, Eric Markusen, Frank Chalk, Kurt Jonassohn, and a few others. The latter category included, for example, Richard Arens (genocide of the Ache in Paraguay); Jon Bridgman (genocide of the Hereros in southwest Africa); Robert Conquest, James Mace, and Roman Serbyn (the Soviet Manmade Famine in Ukraine); Craig Etcheson, David Hawk, and Ben Kiernan (the Cambodian Genocide); and Vahakn Dadrian, Richard Hovannisian, and Yves Ternon (the Armenian Genocide). 
Essentially, over the past 30 years the field has expanded from that small coterie of individuals to hundreds of scholars and graduate students who are broadening the focus of the field and enriching it in ways that were only dreamed of years ago.

During the early years, most scholars focused on one or more of the following: building theoretical constructs in regard to the causes of genocide; developing case studies of genocide; wrestling with the definition of genocide in the UNCG and/or developing their own definition of genocide ${ }^{5}$; collecting first-person accounts of various genocides; analyzing issues germane to prevention and intervention; and creating tools for scholars and students to use in their study of genocide.

As the field of genocide studies slowly began to attract new scholars, the 1980s and 1990s saw the establishment of new genocide centers around the world: the Institute for the Study of Genocide, New York City (1982); the Montreal Institute for Genocide and Human Rights Studies (1986); the Institute for the Research of Crimes Against Humanity and International Law, University of Sarajevo (1992); the Genocide Studies Program at Yale University (1998); the Uppsala Programme for Holocaust and Genocide Studies in Sweden (1998); and the Australian Institute for Holocaust and Genocide Studies (1999). Such centers generally published and disseminated newsletters, conducted research, issued reports and published monographs, established archives, and/or offered courses on different facets of genocide. ${ }^{6}$

Beginning with Charny's Genocide: A Critical Bibliographic Review series, various research tools have been developed by genocide scholars over the years, including, for example, the Encyclopedia of Genocide edited by Charny and the Encyclopedia of Genocide and Crimes Against Humanity edited by Dinah Shelton, The Dictionary of Genocide edited by Samuel Totten and Paul Bartrop, and The Oxford Handbook of Genocide Studies edited by Donald Bloxham and A. Dirk Moses. ${ }^{7}$ These and other works have been particularly useful for instructors who teach courses on genocide and for students attempting to familiarize themselves with various facets of it.

Scores of compilations of essays and/or documents addressing various issues and aspects of genocide have been published as well. Even a truncated list of such publications provides a sense of the eclectic topics, issues, and perspectives addressed in such works: Century of Genocide: Critical Essays and Eyewitness Testimony (1995, 1997, 2004, 2009) edited by Totten and William Parsons; The Coming Age of Scarcity: Preventing Mass Death and Genocide in the Twenty-First Century (1998) edited by Michael N. Dobkowski and Isidor Wallimann; Annihilating Difference: The Anthropology of Genocide (2002) edited by Alexander Hinton; The Specter of Genocide: Mass Murder in Historical Perspective (2003) edited by Robert Gellately and Ben Kiernan; Gendercide and Genocide (2004) edited by Adam Jones; Empire, Colony, Genocide: Conquest, Occupation, and Subaltern Resistance in World History (2008) edited by Moses; The Historiography of Genocide edited by Dan Stone (2008); and Genocide: Critical Concepts in Historical Studies (6 volumes) edited by Moses. ${ }^{8}$

In addition to those mentioned above, there has been an explosion of books, refereed articles, and book chapters on an eclectic array of topics and issues, including genocide theory, causes of genocide, cases of genocide, the impact of colonialism on indigenous groups across the globe, "forgotten" genocides, comparative studies of genocide, prevention of genocide, intervention against genocide, genocide and international law, court cases of genocide, crimes against humanity, war crimes, ethnic cleansing, the aftermath of genocide, and denial of genocide.

Finally, an innovation worth mentioning is French scholar Jacques Semelin's Online Encyclopedia of Mass Violence (OEMV). Initiated in 2004 by Sciences Po 
Paris, Center for International Research and Studies, the OEMV "is a regularly updated electronic database focusing on massacres and genocides of the 20th century.... [It] documents and classifies ... knowledge by continent, country and historical period." In doing so, the OEMV presents "reliable historical description and interdisciplinary analysis of both well-documented and less well-known 20th century massacres."9

Over the years, the increased attention to the subject of genocide resulted from a variety of factors, including

- Interest piqued by the earlier works of genocide;

- Dissolution of the Soviet Union and end of the Cold War;

- Efforts of the genocide institutes around the globe;

- The 100-day genocide in Rwanda in which between 500,000 and one million people were slain;

- The ongoing concern throughout the 1990s that genocide had been and was possibly continuing to be perpetrated in different parts of the former Yugoslavia;

- The establishment of the International Criminal Tribunal for the former Yugoslavia (ICTY) in 1993 to try the alleged perpetrators of crimes (i.e., genocide, crimes against humanity, war crimes) committed during the course of the conflict in the former Yugoslavia;

- The establishment of the International Criminal Tribunal for Rwanda (ICTR) in November 1994 "for the prosecution of persons responsible for genocide and other serious violations of international humanitarian law committed in the territory of Rwanda between 1 January 1994 and 31 December 1994" 10 ;

- The establishment of the International Association of Genocide Scholars (IAGS) in 1994 and its subsequent conferences;

- The massacre (which was ultimately deemed a genocide) of 8,000 Muslim boys and men in Srebrenica in July 1995;

- The adoption of the Rome Statute of the International Criminal Court in 1998;

- An ever-increasing number of university courses being taught on genocide;

- University-based institutes of genocide studies that offer degree programs (primarily master's degrees) in genocide studies ${ }^{11}$;

- Summer institutes with foci on a combination of human rights, crimes against humanity, and/or genocide ${ }^{12}$;

- The creation of the Journal of Genocide Research in 1999;

- The development of the concept of the Responsibility to Protect (R2P);

- The establishment of the International Criminal Court in 2002;

- The explosion of violence in Darfur, Sudan (2003-present);

- The establishment of the International Network of Genocide Scholars (INoGS) in 2005;

- The creation of Genocide Studies and Prevention: An International Journal in 2005; and

- The indictment of Omar al-Bashir on 12 July 2010 on charges of genocide, crimes against humanity, and war crimes.

Increasingly, genocide scholars have presented testimony at tribunals and trials, taken part in UN meetings and governmental hearings germane to crimes against humanity and genocide, and served as investigators into suspected crimes against 
humanity and/or genocide. For example, William Schabas has testified at the ICTR and served as one of three international members of the Sierra Leone Truth and Reconciliation Committee (2002-2004). Ton Zwaan, a professor in the Department of Anthropology and Sociology at the University of Amsterdam and a research associate with the university's Centre for Genocide Studies, presented expert testimony at the ICTY. Martin Mennecke, professor of international law at the Royal Danish Defence College, has served as an advisor to the Danish Government on the International Criminal Court since 2004 and continues to participate in diplomatic meetings in The Hague, at the European Union, and at the United Nations. In 2004, Eric Markusen and Samuel Totten served as investigators on the US State Department's Atrocities Documentation Project and conducted interviews with black African refugees from Darfur who had fled to Chad following scorched earth attacks by the government of Sudan and Janjaweed (the express purpose of the project was to collect data so that they could be analyzed by the US State Department to ascertain whether genocide had been perpetrated or not by the government of Sudan). ${ }^{13}$

Today, the field of genocide studies is at a major turning point. As the pioneers of genocide studies enter their 80s and begin to slow down, the second-, third-, and fourth-generation scholars, with new research agendas and, in certain cases, new methodologies, are taking over the field. In addition to conducting new research into old cases of genocide (and revising findings that had largely been accepted as givens), they are, for example, examining cases of atrocity crimes that were rarely if ever examined through the lens of genocide (e.g., the atrocities perpetrated during the Dirty War in Argentina between 1976 and 1983) and raising new and critical questions about key issues (e.g., whether interventions to halt gross human rights violations might result in an escalation of atrocities and potentially genocide), and in doing so they are broadening, deepening and enriching the field. As a result, over and above macro-studies of genocide, we have micro- and meso-studies (and their various relationships), transnational genocide studies, critical genocide studies, the ramifications of colonialism and genocide, and the propounding of new theories regarding the causes of atrocity crimes, and so forth.

Some second-, third-, and fourth-generation scholars have begun scrutinizing previously overlooked archives in search of primary documents about genocides perpetrated a century or more ago in order to glean new insights into the antecedents, processes, and ramifications of such genocides. A small number of others are traveling to refugee camps and areas of conflict to carry out research. The upshot is that the boundaries of genocide studies are being stretched, issues delved into more deeply, and old conceptions revised. Not only is that as it should be but it is healthy and bodes well for the future of the field.

\section{The Critical Need to Address the Toughest Barriers to Prevention and Intervention}

\section{The Issues of Realpolitik and the Lack of Political Will}

Over the past decade or so, both a court decision and a wide array of reports by various organizations have spelled out the need for the international community and individual states to be more proactive in addressing situations that are moving toward genocide or have already descended into genocide. Among such organizations and their respective decisions/reports are the International Court of Justice (Bosnia and Herzegovina $v$. Serbia and Montenegro: Case Concerning the Application of the Convention on the Prevention and Punishment of the Crime of Genocide) ${ }^{14}$; the International Com- 
mission on Intervention and State Sovereignty, commissioned by the United Nations and established by the Government of Canada (Report of the International Commission on Intervention and State Sovereignty) ${ }^{15}$; the United States Holocaust Memorial Museum and the US Institute of Peace (Preventing Genocide: The Report of the Genocide Prevention Taskforce $)^{16}$; and Harvard University's John F. Kennedy School of Government/Carr Center for Human Rights Policy (MARO: Mass Atrocity Response Operations: A Military Planning Handbook). ${ }^{17}$ All of these documents share the view that the responsibility to protect those in danger of being subjected to mass violence trumps state sovereignty. That is, a state is responsible for protecting its own citizens and if it does not or cannot do so, then other nations across the globe have the responsibility to intervene and protect the individuals in danger of being seriously harmed or killed. The emergence of the concept of R2P represents a sea change vis-à-vis the longheld perspective of the sacrosanctness of state sovereignty. Essentially, the concept of R2P runs counter to a state's claim that state sovereignty prevents other nations from interfering in their so-called "internal affairs" when it is grossly mistreating its citizens or allowing a renegade group to violently harm its citizens.

R2P complements a rather remarkable judicial decision in regard to state responsibility to prevent genocide. What was addressed in part dealt with the issue of whether states are legally obligated to attempt to prevent genocide. More specifically, for over five decades (roughly from 1948 to 2000) scholars and others debated whether the UNCG legally obligates states to attempt to prevent genocide. Most asserted that while there is an inherent moral obligation to do so, there was no concomitant legal obligation. However, in the International Court of Justice's (ICJ) case of Bosnia and Herzegovina v. Serbia and Montenegro, the ICJ held that states do, in fact, have a legal obligation to prevent genocide. ${ }^{18}$

While the new paradigm of R2P is still emergent, it offers at least some hope for the future as it seems to suggest that the international community is beginning to take the seemingly ubiquitous perpetration of mass atrocities more seriously. Still, it is much too soon to be jubilant. It is one thing to create and support such an approach and quite another to act upon it. It is impossible to forget that the very nations that welcomed R2P have been many of the same ones that ratified the UNCG and then brazenly ignored, time and again, their promise to prevent genocide. Realpolitik, the lack of political will, and economic interests all played a part in the lack of timely and effective action.

Realpolitik, of course, drives decision making at the national and international levels, including at the UN Security Council and among the members of the P5 (i.e., United States, Great Britain, France, China, and the Federation of Russia). Until it can be overcome, realpolitik will override many, if not most, of the good intentions behind R2P and the new perspectives and approaches previously mentioned regardless of how ardently supported they are. ${ }^{19}$ To believe otherwise verges on naiveté. That is not to say that such decisions and conceptual frameworks do not contribute by chipping away at the dominance of realpolitik, but when the impediments to timely and effective action (i.e., realpolitik, a lack of political will, and economic interests) are as ingrained as they are, it is going to take much, much more than a single concept to alter them in any real way. ${ }^{20}$

So, while R2P is an effort in the right direction, when push comes to shove, what is going to prevent nations from resorting yet again to realpolitik when a genocidal crisis erupts? Any entity? Will there be any consequences ${ }^{21}$ ? Or will it simply result in some finger pointing and a little embarrassment? 
In the end, any reaction or consequence will likely be inconsequential. Nothing that will rock or threaten a government or nation's well-being. Nothing punitive.

This is exactly why those who are vitally concerned with preventing and intervening against genocide (scholars, human rights activists, non-governmental and intergovernmental personnel, etc.) need to zero in on addressing how realpolitik can at least be increasingly softened as it relates to stanching crimes against humanity and genocide. The same is true in regard to the lack of political will. And a purported lack of resources for prevention and intervention missions must be overcome. Period.

To avoid focusing on such issues and impediments will simply prolong their effects when the time comes once again, and it will, to act to save the lives of hundreds of thousands of people. Right now, the lack of significant work on this front plays directly into self-deception and willed blindness, both of which make a mockery of much of the assembly-line-like churning out of reports, books, and articles that we, genocide scholars, are so prone to producing.

\section{Reforming the Operation and Procedures of the UN Security Council and the Make-up and Operation of the Permanent Five}

Over the past couple of decades many have looked askance at the make-up (and privileging) of the P5 of the UN Security Council, the power of the veto wielded by each member of the P5, the way in which realpolitik drives the decisions of each member of the P5, and the Council's extremely poor record when it comes to the prevention of and intervention against genocide. The P5 of the UN Security Council constitutes an elite club made up of the US, Britain, France, China, and Russia. Important benefits that members enjoy include (1) being the only permanent members of the Security Council (all other members serve on a rotating basis) ${ }^{22}$ and (2) a special veto power over votes on any and all matters. In regards to the latter, if one of the P5 vetoes a resolution, it is automatically defeated, regardless of how pressing the issue may be or how ardently other members might support it. Thus, in a body composed of 192 nations, a single veto by a single member of the P5 can prevent an intervention to attempt to halt crimes against humanity and/or genocide.

Questions abound as to why those five countries should be privileged over all other countries in the world. While they are certainly among the most powerful and richest nations in the world, some have argued that in this day and age other countries, which have gained a toehold on power, wealth, and influence internationally, should be considered for potential membership in the elite club. In fact, for years, Germany, France, and India have called for reform to the UN Security Council and for an increase to the number of permanent members on the Council. Since at least since 2007, German Chancellor Angela Merkel has campaigned for a permanent German seat on the Security Council. ${ }^{23}$ In November 2010, US President Barack Obama entered the fray, asserting that India should become a permanent member of the Council. ${ }^{24}$

Still others abound that permanent membership should be more diverse, including at least one state from Africa and one from Central or South America. They argue that such inclusivity might result in the Permanent Members of the Security Council being more concerned, and thus proactive, when it comes to crises in thirdworld nations. Maybe, but it seems dubious. After all, each permanent member would still wield the all-powerful veto, which would allow it to squelch any motion or resolution that it perceived as counter to its own or its allies' interests. 
Adding grease to the fire, many, if not most, of the P5's votes regarding intervention in genocide in the past have been driven by realpolitik. In other words, the P5 have not been concerned primarily with the fate of the potential victims of genocide but much more focused on whether intervening would be good for themselves or their allies. As the cliché goes, nation states do not have consciences. Concomitantly, the type of mission-Chapter VI (peacekeeping) or Chapter VII (peace enforcement) of the Charter of the United Nations ${ }^{25}$-is largely dictated by the P5 as well. Thus, instead of sending a robust mission in a timely fashion with a mandate that allows the mission's troops to handle a job properly, the P5 play politics and often approve missions that are sorely inadequate for the job. This is true for a whole host of reasons, but the main point here is that the P5 virtually take on the God-like role of deciding who will live and who will die.

It is also a fact that when the UN Security Council actually chooses to act in the face of genocide, it is more apt to do so after the genocide has broken out-that is, after a great deal of killing and other destruction has occurred rather than at an earlier point when the killing and destruction could have been prevented. That hardly honors the promise stated in Article 1 of the UNCG: "The Contracting Parties confirm that genocide, whether committed in time of peace or in time of war, is a crime under international law which they undertake to prevent and to punish." 26

Those who think or claim that reform to the Security Council and the P5 is an intractable issue could not be more wrong. Sooner or later everything is subject to change; it is only a question of how long it will be until the change is made, who will be behind the change, and how it will be made. With this in mind, genocide scholars need to begin to focus on the reformation of the Security Council with an eye toward making recommendations to the UN Secretary General and UN General Assembly. Certainly a team comprised of astute political scientists, international relations specialists, international law specialists, and ethicists, among others, could make a strong case for reform and develop significant ways to help reorient the UN Security Council so that it would at least be more open to the possibility of preventing mass atrocities before they break out and, in the event of an outbreak of genocide, be more proactive and conscientious in developing more timely, efficient, and effective missions. At a minimum, it seems, the following should be the focus of analysis and, ultimately, action: whether a Permanent Five (or any other number) should remain part and parcel of the UN Security Council; whether any member of the Security Council should hold an all-powerful veto; if the concept of the Permanent Group remains in place, how it could be made more diverse and fair so that thirdworld nations do not remain second-class members of the UN; how can the UN Security Council (and/or the UN General Assembly) be made more proactive in addressing gross human rights violations, crimes against humanity, and genocide; and a re-examination of the need to create a strong, well-trained, and well-resourced UN rapid-action force whose specialty would be stanching crimes against humanity and genocide. At one and the same time, such an analysis should include serious consideration of the analysis, insights, and suggestions posited in recent scholarly works and reports on the need to reform the UN Security Council in particular and the UN in general. An excellent starting point would be the host of issues that Michael Barnett examines in Eyewitness to a Genocide: The United Nations and Rwanda. Barnett analyzes how the make-up and operation of the UN bureaucracy contributed to the decisions, and lack thereof, to halt the Rwandan Genocide and how those working at the UN approached the issue of Rwanda not as individuals 
concerned with saving lives but rather as members of a bureaucracy, ${ }^{27}$ which basically caused decent human beings to adhere to institutional norms that militated against their zeroing in on the genocide as something that needed to be halted immediately.

\section{Crimes Against Humanity 28 Initiative}

In 2008, the Crimes Against Humanity Initiative was established by a group of international law specialists to "study the need for and to ultimately elaborate a comprehensive international convention on the prevention and punishment of crimes against humanity." 29 In August 2010, the group completed its work on the development of its Proposed International Convention for the Prevention and Punishment of Crimes Against Humanity. Meetings then ensued with academics, diplomats, and members of civil society to discuss the proposed convention and seek support for it.

The proposed convention comprises "three core pillars": prevention, punishment, and effective capacity building to facilitate such prevention and punishment. Prevention, then, is purportedly an essential component of the proposed convention. ${ }^{30}$

Ostensibly, those who developed the proposed convention on crimes against humanity believe that it can replace the UNCG for, some of them argue, it covers virtually the same crimes as the UNCG and would do away with the need to engage the thorny issue of intent. That is, unlike the UNCG, where the intent of the perpetrators to destroy in whole or in part a particular group, as such, must be established in order for an act to be considered a case of "genocide," intent is not needed (or, put another way, not a factor) in determining whether one act or another constitutes a crime against humanity. ${ }^{31}$

Time and again in the recent past, both individual states and the international community sat and watched as mass atrocities unfolded before deciding whether they would act to stanch them. Reportedly, officials were either not sure (1) whether the actions constituted genocide rather than civil war, ethnic cleansing, crimes against humanity, or something else altogether and/or (2) whether the actual intent of the perpetrators was to destroy in whole or in part a particular group protected under the UNCG. As a result, state and/or international community officials often insisted on waiting for additional evidence, even as tens and hundreds of thousands were slaughtered, before making a decision one way or the other. Essentially, officials seemed to be saying, "Well, if it's not a case of genocide then we do not have to act, and since genocide is so difficult to ascertain, if not prove, we'd better take our time and be absolutely sure before we make our final decision." 32 A classic example of such wavering and dithering took place during the 1994 Rwandan Genocide. Not only did the UN fail to act, but the US also used its "confusion" and "lack of certainty" as a convenient excuse to do nothing. The fact is, the US knew full well what was happening in Rwanda but wanted to avoid, at all costs, sending troops to intervene. Those proposing the new convention seem to be saying that since crimes against humanity are easier to establish than genocide is, once the International Convention for the Prevention and Punishment of Crimes Against Humanity goes into effect neither states nor the international community will be able to hem and haw, at least not legitimately, over what to call atrocities before choosing to intervene or not. Neither will they be hampered by the need to establish intent.

If the proposed convention results in states, individually and collectively, actually becoming more proactive in addressing atrocity crimes and carrying out preventive and interventive efforts in a timely and effective manner, then that would certainly constitute a watershed event. But that is a huge if. 
It seems as if realpolitik will come into play just as strongly as ever when a nation or the UN (here I am thinking of the UN Security Council, particularly the P5) is faced with a potential or actual outbreak of crimes against humanity or genocide. Unless I am missing something, it seems as if the steering committee and its supporters are being rather naïve when it comes to their belief in the efficacy of their proposed convention. Why, pray tell, would the international community suddenly lose its ostensible aversion to carrying out preventive and interventive efforts (and particularly those that are timely and effective) solely because of a new convention? And why would states suddenly succumb to readily carrying out preventive measures and interventive missions that, as most seem to fear, could cost them dearly in a variety of ways: politically at home, politically internationally by possibly angering both allies and enemies, militarily as a result of soldiers coming home in body bags, and monetarily? And why would countries all of a sudden be more willing to join preventive and interventive efforts when many already fear potential quagmires (here, the United States' disastrous intervention in Somalia in 1993 comes to mind), including those from which they might not be able to extricate themselves for years (and here US involvement in Vietnam comes to mind along with the more recent examples of Iraq and Afghanistan)?

Indeed, one has to wonder why those proposing the new convention believe that much of anything will really change as a result of the convention. It is understandable why they may believe that it will be much easier to prosecute atrocities as crimes against humanity than as genocide, but prevention and intervention are something altogether different.

The major point here, again, is that a tremendous amount of work needs to be done to overcome realpolitik and a lack of political will. To not face this fact is sheer folly. Sadly, the enactment of additional human rights law is not enough to accomplish material change in global politics.

\section{A Critical Need to Be More Inclusive}

Just as the number of scholars in the field of genocide studies has increased exponentially over the past decade and a half so has the number of topics, issues, and cases that are now being addressed by these scholars. ${ }^{33}$ What is rarely addressed by genocide scholars, though, are issues such as conflict resolution, mediation, conflict prevention, conflict management, peacemaking, peacebuilding, peace maintenance, peace enforcement, two-track diplomacy, multi-track diplomacy, sanctions, sanctions regime, humanitarian assistance, and international development (e.g., environmental sustainability and sustainable economic and human development). Each of the aforementioned concepts-generally studied by those in the fields of international relations (IR) and peace studies-merits serious consideration by genocide scholars. By overlooking, or outright ignoring, the research and practical applications of such issues, genocide scholars may be overlooking concepts, research, and effective means to detect and head off conflict that may have the potential to explode into crimes against humanity and/or genocide. By focusing on such issues, the field could potentially move from its heavy emphasis on intervention to one more geared to prevention. The most salutary effect would be saving tens, if not hundreds, of thousands of lives.

Furthermore, by becoming conversant with select concepts and approaches studied by researchers in other fields, both through research and application, genocide scholars can begin to address conflicts and cleavages that, if left to fester, could once again burst into crimes against humanity or genocide. While some research on post-genocide societies exists, much more needs to be done. 
It would also behoove IAGS and INoGS to extend personal invitations to peace and IR researchers and practitioners involved in theoretical work and research germane to conflict and conflict resolution to (1) join IAGS and/or INoGS, (2) co-conduct research, (3) publish in Genocide Studies and Prevention and the Journal of Genocide Research, and (4) attend and present at IAGS and INoGS conferences. Such trans-disciplinary collaboration has the potential to enrich both fields and lead to significant breakthroughs on prevention and intervention.

Genocide scholars should also collaborate more with international human rights organizations, scholars, and activists. Here one thinks of the important work of Human Rights Watch (HRW), and particularly Dr. Alison des Forges, in Rwanda in the early 1990s as HRW tracked, analyzed, and reported on new violations of human rights infractions, including test massacres, as they took place. ${ }^{34}$ At the time, only a tiny number of genocide scholars had a clue as to what was happening in Rwanda, and that could have been avoided if genocide scholars had either been more astute, more tuned into the significance of the ever-increasing violations of human rights of the Tutsi, or had been working side-by-side with human rights specialists in monitoring the situation. While genocide scholars certainly appreciate the value of tracking such violations, very few did then, just as very few do now, and certainly not as assiduously as HRW or Amnesty International.

\section{Monitoring "Hot Spots"}

For well over two decades various scholars, and particularly first-generation genocide scholars, have talked about the need for and value of genocide early warning signals and genocide early warning systems. Early on, there was a flurry of activity along those lines-plans, papers, and talks-but to date all the good intentions have resulted in naught.

Both the UN and individual states, including the US, have also addressed the need for a genocide early warning system and have actually put in great amounts of time, thought, and energy toward developing one, but such a system remains more of an idea than a reality. One has to wonder, though, just how valuable such a system would be in the hands of, say, the UN Security Council. After all, there was no dearth of information about the 1994 Rwandan Genocide or the outbreak of violence in Darfur and yet the responses of the UN and individual states to each were anemic, apathetic, and pathetic.

Some have suggested that reports by journalists could more or less serve as early warning signals. While some have, it is also a fact that journalists are neither trained to decipher potential early warning signals nor in the business of doing so. It is also a fact that journalists have misjudged and misinterpreted outbreaks of violence. That is not surprising, nor is it an indictment of them.

That said, with their expertise and abiding interests, genocide scholars could serve the double duty of monitoring conflicts and ascertaining whether outbreaks of violence are cases, for example, of internecine fighting, crimes against humanity, genocide, or something else. ${ }^{35}$ To do this in the most effective manner possible, scholars would need to be on the ground in "hot spots" where conflict is brewing or violence has already broken out. To date, though, very few genocide scholars have made the effort to travel, live, and conduct research in such places.

By being on the ground in hot spots, researchers are likely to glean information that is not readily available from other sources. ${ }^{36}$ Over and above the locals, I am thinking about such individuals as locally based reporters, non-governmental personnel, intergovernmental personnel, local and regional leaders, and possibly even rebel groups and military personnel. While collecting valuable data, genocide scholars 
could monitor political tremors in the country, assess the reactions of the people to such tremors and the reactions of the government to the reactions of the people, obtain information that could serve as genocide early warning signals, and act as early warning signalers. Indeed, if scholars were to provide key information and daily, if not hourly, updates to media sources across the globe, international human rights organizations, government officials in different countries, the UN, and fellow genocide scholars, it would be virtually impossible for UN officials or individual states to feign ignorance about such events. They certainly would not be able to make absurd statements about not knowing, as US President Bill Clinton did, some four years after the 1994 Rwandan Genocide, as he spoke with a small gathering of survivors on the tarmac of the Kigali International Airport in Rwanda:

It may seem strange to you here, especially the many of you who lost members of your family, but all over the world there were people like me sitting in offices, day after day after day, who did not fully appreciate the depth and the speed with which you were being engulfed by this unimaginable terror. ${ }^{37}$

With today's technology—satellite (SAT) phones, Internet, mobile phones, social media sites (e.g., Twitter), and so forth-it is possible to provide regular updates to those outside the region of conflict and relay key information and insights that might not otherwise reach the outside world. Not infrequently, the international media might not have a presence in a specific region prior to the outbreak of violence, might not be able to get into the country or access the region once violence has broken out, or might not be able to get in until violence is well under way, and thus an individual on the ground who relays information to outside actors can be invaluable. ${ }^{38}$

The safety of individuals or a team would be a major concern in such situations, but there are always individuals who are willing to risk their lives to help others. And it is true that they may end up getting killed, but that is a risk that they would have to be willing to take. ${ }^{39}$

\section{Is Activism by Genocide Scholars Counterproductive or is a Lack of Activism by Genocide Scholars Telling in Its Own Way?}

Over the past several years, a coterie of genocide scholars have criticized certain other genocide scholars for what they refer to as "their activism" (e.g., co-authoring resolutions calling on the international community to act to stanch contemporary crimes against humanity and/or genocide, signing resolutions, writing editorials about governmental and intergovernmental actions or inactions during periods of crimes against humanity and/or genocide, speaking at rallies and anti-genocide conferences, etc.). Basically, the former claim that scholars who engage in activism around the issue of genocide automatically call into question the validity of their scholarship. Some have gone so far as to wonder in print whether such individuals even merit the title of "scholar."

Henry Huttenbach, a historian and early genocide scholar, is one of those who look askance at so-called "scholar activists." In an article entitled "Can Genocide Be Prevented? No! Yes? Perhaps," he asserts,

A primary purpose of Genocide Studies is, of course, the hope that policy makers will be assisted by the insights of researchers. But theirs is to be activists, the opposite mindset of disinterested scholarship. The two-research and public policy-must be carefully kept distinct. Their blurring leads to scholar-activists, a slippery slope to polemics and the loss of credibility. It is a position held by Genocide Research (sic), a stance that clearly and unambiguously distinguishes it from other journals dealing with genocide but tempted to opening the door to partisan prescriptions. ${ }^{40}$ 
Here, Huttenbach clearly shows that he readily accepts-no questions asked, no doubts pondered, no exceptions envisioned-the traditional perception of the scholar as one who can be, should be, and is wholly "disinterested" vis-à-vis his or her subject of research. So be it. That is his opinion, his prerogative. And no doubt there are many who likely agree with him and decry so-called scholar activists. But, speaking for myself and only myself, assuming that for all of eternity I have one life to live on this planet, I am not about to stand by and be silent in the face of mass murder. It is as simple (and profound) as that. Period.

Interestingly, certain leaders of INoGS have repeatedly criticized and mocked the title of IAGS's journal, Genocide Studies and Prevention (GSP). In doing so, they insinuated that neither IAGS members nor the editors were serious scholars since they ostensibly mixed activism (read: prevention) with scholarship. One has to wonder whether such critics also hold in contempt those physicists, chemists, and engineers who founded and/or wrote for The Bulletin of Atomic Scientists, an activist journal if there ever was one. ${ }^{41}$ The journal's past and present board members read like a Who's Who of some of the world's most renowned scientists. ${ }^{42}$ Over the years, its regular contributors include such luminaries as Bernard T. Feld, a key member of the Manhattan Project who served as an assistant to Enrico Fermi and later became a professor of physics at MIT; Philip Morrison, who served as the group leader and a physicist on the Manhattan Project at the laboratories of the University of Chicago and Los Alamos and later became a professor of physics at MIT where he conducted research on quantum electrodynamics, nuclear theory, radiology, isotope geology, and, since the $1950 \mathrm{~s}$, cosmic-ray origins and propagation, gamma-ray astronomy, and other topics in high-energy astrophysics and cosmology; and George Kistiakowsky, chemistry professor at Harvard who was a member of the Manhattan Project and later served as US President Dwight David Eisenhower's Science Advisor. The point is, every single scientist mentioned here (and in the Endnotes) was concerned with and spoke out about the dangers of the proliferation of nuclear weapons and yet continued to produce high quality research and, in some cases, made world-shaking discoveries.

A blanket statement that genocide scholars who are vitally concerned with the prevention of and intervention in genocide are dubious scholars, cannot disentangle their activism from their scholarship, and are lesser lights because of their activism is ludicrous. Indeed, such remarks call into question the logic and moral compasses of those who utter them. One has to wonder how an individual can work in the field of genocide studies and not be vitally concerned with preventing genocide and, when crimes against humanity and/or genocide are about to or do actually erupt, avoid at all costs registering one's dismay and concern and avoid issuing criticism if the international community does not act to stanch such atrocities in a timely and effective manner.

\section{Conclusion}

Only time, of course, will tell how the field of genocide studies will evolve from this point forward. Personally, I hope the field works toward and has a positive impact on bringing about a regime of prevention and intervention in which prevention is a given and intervention, when needed, is quick, efficient, and effective. At the same time, I hope that the field continues to attract new scholars who are committed to producing outstanding scholarship while simultaneously acting on their humanity to help others in dire need. Finally, I hope all remember, and act upon the fact, that suffering does not end once the killing has ended. 


\section{Notes}

1. I sincerely thank Henry Theriault for his close reading of this article and various editorial suggestions.

2. I also believe that a lack of caring on the part of various intergovernmental and governmental officials also constitutes a major impediment to genocide prevention and intervention. This is an issue that has not been researched but one that demands it.

3. Leo Kuper, Genocide: Its Political Use in the Twentieth Century (New Haven, CT: Yale University Press, 1981); Kuper, The Prevention of Genocide (New Haven, CT: Yale University Press, 1985).

4. Israel W. Charny, ed., Genocide: A Critical Bibliographic Review, vol. 1-4 (London: Mansell/ New Brunswick, NJ: Transaction, 1988-2003); Samuel Totten, ed., Genocide: A Critical Bibliographic Review, vol. 5-9 (New Brunswick, NJ: Transaction, 2005-2012); Charny, ed., Encyclopedia of Genocide, 2 vols. (Santa Barbara, CA: ABC-CLIO, 2010); Charny, Genocide Prevention Now: A Holocaust and Genocide Review on the Internet for All People, 2010, http://www.genocidepreventionnow.org (accessed 14 September 2011).

Each volume of Genocide: A Critical Bibliographic Review, the most recent of which was published in 2010 , consists of a set of critical essays and a critical annotated bibliography. The volumes have addressed an eclectic array of topics and issues (e.g., the plight and fate of women during and after genocide, the genocide of indigenous peoples, the impediments to genocide prevention and intervention). Among the contributors to Genocide are Howard Adelman, Alex Alvarez, M. Cherif Bassiouni, Israel W. Charny, Frank Chalk, Vahakn Dadrian, Christian Davenport, Nicole Hallett, Barbara Harff, Maureen Hiebert, Herb Hirsch, Robert Hitchcock, Kurt Jonassohn, Richard Hovannisian, Leo Kuper, Judy Ledgerwood, George Lopez, Cyanne Loyle, James Mace, Eric Markusen, Ivana Macek, Martin Mennecke, Valerie Oosterveld, Dominik Schaller, William Schabas, Gregory Stanton, Roger Smith, Colin Tatz, Henry Theriault, Samuel Totten, Hannibal Travis, and Lawrence Woocher.

5. See A. Dirk Moses, "Lemkin, Culture, and the Concept of Genocide," in The Oxford Handbook of Genocide Studies, ed. Donald Bloxham and A. Dirk Moses (New York: Oxford University Press, 2010). In this chapter Moses asserts, "To a great extent, genocide studies has yet to break out of its self-imposed isolation. Part of the problem is that Lemkin's revealing correspondence and invaluable manuscripts languish in archives.... This problem is compounded by the priorities of the self-proclaimed 'pioneers of genocide studies'-those social scientists writing about genocide in the 1980s and 1990s-who paid Lemkin lip service for 'discovering' genocide by presuming to improve his definition without undertaking the necessary systematic reconstruction and explication of his ideas" (20). First, such snarky comments are, unfortunately, typical of some of the thirdgeneration genocide scholars. Second, perhaps Moses would prefer the term "first and second generation of genocide scholars" rather than "pioneers of genocide studies," but then again maybe not since he also seems to have a problem elsewhere with the term or notion of "genocide studies." Third, interestingly, well over half the individuals highlighted in Pioneers of Genocide Studies, ed. Samuel Totten and Steven Leonard Jacobs (New Brunswick, NJ: Transaction, 2002)—with whom and with which, respectively, Moses seems to have a problem-are referenced (most more than once) in The Oxford Handbook of Genocide Studies, which Moses edited (including Israel W. Charny, Helen Fein, Herb Hirsch, Ben Kiernan, Irving Louis Horowitz, Kurt Jonassohn, James Mace, Eric Markusen, R.J. Rummel, Roger Smith, and Samuel Totten). The point is, perhaps some of their work is actually worthwhile. Tellingly, some contributors to Pioneers are acknowledged for their pioneering efforts by contributors to the Handbook (and the word "pioneer" is actually used to describe them). Fourth, Moses does not appear to understand that the "social scientists" were not criticizing Lemkin or his definition but rather taking to task the compromised definition that eventually made it into the UN Convention on the Prevention and Punishment of Genocide. Finally, Moses is incorrect when he suggests that the early scholars in the field did not thoroughly examine Lemkin's writing 
and ideas. Furthermore, to say they simply paid "lip service" to him for "discovering" genocide is nonsensical. Many, in fact, revered, and continue to revere, Lemkin; and none of them, and I know or knew them all, ever thought Lemkin "discovered" genocide. Such an assertion is not only outrageous but ludicrous.

Over the years, various INoGS leaders have had a propensity to make self-congratulatory comments-often couched in what they must think are clever subtleties-about IAGS, its membership, and its journal, Genocide Studies and Prevention. For example, in his introduction to the March 2006 issue of the Journal of Genocide Research (JGR), Jürgen Zimmerer wrote, "[T]he generational, geographical and thematic widening of the field is reflected in the goals of JGR, the principal if not sole voice of a global community of genocide scholars." Jürgen Zimmerer, "From the Editor: Towards Transnational Genocide Studies: Recent Trends and Future Development in Genocide Research," Journal of Genocide Research, 8 no. 1 (2006): 3-5, 5; emphasis added. Such self-congratulatory, highly incorrect, and arrogant assertions have no place in the field of genocide studies.

6. Additional genocide research centers continue to be established across the globe. Two notable centers established relatively recently are Rutgers University's Center for the Study of Genocide and Human Rights in the United States and the Center for Genocide Studies, Universidad Nacional de Tres Febrero in Argentina.

7. Charny, Encyclopedia; Dinah Shelton, ed., Encyclopedia of Genocide and Crimes Against Humanity (Detroit: Macmillan, 2005); Samuel Totten and Paul Bartrop, eds., The Dictionary of Genocide (Westport, CT: Greenwood Press, 2008); Bloxham and Moses, The Oxford Handbook of Genocide Studies.

8. Samuel Totten and William Parsons, eds., Century of Genocide: Critical Essays and Eyewitness Testimony (New York: Garland, 1995, 1997; New York: Routledge, 2004, 2009); Michael N. Dobkowski and Isidor Wallimann, eds., The Coming Age of Scarcity: Preventing Mass Death and Genocide in the Twenty-First Century (Syracuse, NY: Syracuse University Press, 1988); Alexander Hinton, ed., Annihilating Difference: The Anthropology of Genocide (Berkeley: University of California Press, 2002); Robert Gellately and Ben Kiernan, eds., The Specter of Genocide: Mass Murder in Historical Perspective (Cambridge: Cambridge University Press, 2003); Adam Jones, ed., Gendercide and Genocide (Nashville, TN: Vanderbilt University Press, 2004); A. Dirk Moses, ed., Empire, Colony, Genocide: Conquest, Occupation, and Subaltern Resistance in World History (New York: Berghahn, 2008); Dan Stone, ed., The Historiography of Genocide (Basingstoke, UK: Palgrave Macmillan, 2008); A. Dirk Moses, ed., Genocide: Critical Concepts in Historical Studies, 6 vols. (New York: Routledge, 2010).

9. “The Project," Online Encyclopedia of Mass Violence, 2004, http://massviolence.org/Theproject (accessed 29 August 2011).

10. International Criminal Tribunal for Rwanda, 8 November 1994, http://www.unictr.org/ AboutICTR/GeneralInformation/tabid/101/Default.aspx (accessed 19 October 2011).

11. Among such institutions are Kean University, New Jersey (MA in Holocaust and Genocide Studies); Richard Stockton College of New Jersey (MA in Holocaust and Genocide Studies); Kingston University in London, England (MA in Human Rights and Genocide Studies); European University Viadrina in Frankfurt (MA in Human Rights and Genocide); University of Amsterdam (master's degree in Holocaust and Genocide Studies); Uppsala University (master's program in Holocaust and Genocide Studies); Rutgers University (MS in Global Affairs with a concentration in genocide, political violence, or human rights); and the National University of Rwanda (MA in Genocide Studies). In 1998, Clark University (Worcester, MA) established the first PhD program in Holocaust and Genocide Studies to be offered anywhere in the world.

12. A unique program that is remarkable both for the eclectic nature of the students it attracts and the quality of its faculty is the Zoryan Institute's International Institute for Genocide and Human Rights Studies. Initiated in 2002, over the course of the past decade, graduate students from around the globe (e.g., Argentina, Armenia, Austria, Canada, the Czech Republic, Germany, Holland, Italy, Lebanon, Turkey, the United 
Kingdom, the United States, and Uruguay) have taken part in its comprehensive twoweek, 65-hour graduate-level seminar. Program faculty have included Taner Akcam, Joyce Apsel, Yair Auron, Doris Bergen, Vahakn N. Dadrian, Maureen Hiebert, Alex Hinton, Herb Hirsch, Richard Hovannisian, Jacques Kornberg, Eric Markusen, Robert Melson, Simon Payaslian, William Schabas, Roger Smith, Gregory Stanton, Scott Straus, Samuel Totten, and Ernesto Verdeja. To date, some 250 students have completed the course.

13. For a description of the Atrocities Documentation Team and an analysis of its findings, see Genocide in Darfur: Investigating Atrocities in the Sudan, ed. Samuel Totten and Eric Markusen (New York: Routledge, 2006).

14. Bosnia and Herzegovina v. Serbia and Montenegro: Case Concerning the Application of the Convention on the Prevention and Punishment of the Crime of Genocide, Judgement (26 February 2007), International Court of Justice, http://www.icj-cij.org/docket/files/91/ 13685.pdf (accessed 1 August 2011).

15. Gareth Evans and Mohamed Sahnoun, Co-Chairs, The Responsibility to Protect: The Report of the International Commission on Intervention and State Sovereignty (Ottawa: International Development Research Centre, December 2001), http://responsibilitytoprotect.org/ ICISS\%20Report.pdf (25 August 2011).

16. Madeleine K. Albright and William S. Cohen, Preventing Genocide: A Blueprint for U.S. Policymakers (Washington, DC: Genocide Prevention Task Force, 2008). For critiques of this report, see "Symposium on the Genocide Prevention Task Force Report," Genocide Studies and Prevention 4, no. 2 (2009).

17. Sarah Sewall, Dwight Raymond, and Sally Chin, MARO: Mass Atrocity Response Operations; A Military Planning Handbook (Cambridge, MA: Harvard University, 2010). For an interesting set of critiques of $M A R O$, see "Symposium on MARO: Mass Atrocity Response Operations," Genocide Studies and Prevention 6, no. 1 (2011).

18. Bosnia and Herzegovina v. Serbia and Montenegro.

19. If the concept of the responsibility to protect becomes widely accepted and automatically acted upon when humanitarian crises arise, realpolitik will have been overcome. But how likely is such a scenario? Not likely, I fear.

20. Interestingly, a recent book, The Evolution of the Responsibility to Protect: Imperfect Duties?, ed. Brett O’Bannon and John Roth (New York: Routledge, 2011) contains chapters with the following titles: "Understanding the Gap between the Promise and the Reality of 'The Responsibility to Protect'"; "Why the Responsibility to Protect (R2P) as a Doctrine or (Emerging) Norm Is on the Decline"; and "The Responsibility to Protect and the Limits of International Authority."

21. Even if a state feels pressured by the international community to act, it could easily manufacture a slew of excuses to cover its commitment to realpolitik, lack of political will, and so forth: financial issues, a lack of adequately trained personnel, a military that is already over-stretched protecting its own borders, fighting its own wars, or committed to other UN missions, and so on.

22. Ten non-permanent members are elected to serve on the Security Council by the General Assembly for two-year terms. They are not eligible for immediate re-election. The number of non-permanent members was increased from six to ten by an amendment to the UN Charter which came into force in 1965.

23. In fact, as recently as June 2011, German Chancellor Merkel called for "an urgent reform" to the UN Security Council. "Merkel Calls for Reform of the UN Security Council," Zimbio, 5 June 2011, http://www.zimbio.com/Chancellor+Angela+Merkel/articles/ G-eaDfuDEKk/Merkel+calls+reform+UN+Security+Council (accessed 19 October 2011).

24. Seemingly, Obama's sentiments were far from altruistic for his assertion was purportedly part and parcel of strengthening US ties with India and helping to create more commercial opportunities while also "attempting to check the influence of an increasingly assertive China." Sheryl Gay Stolberg and Jim Yardley, "Countering China, Obama Backs India for U.N. Council," New York Times, Global Ed., Asia Pacific, 8 November 2010, www.nytimes.com/2010/11/09/world/asia/09prexy.html (accessed 19 October 2011). 
25. "Chapter VI: Pacific Settlement of Disputes," Charter of the United Nations, http:// www.un.org/en/documents/charter/chapter6.shtml (accessed 7 July 2011); "Chapter VII: Action with Respect to Threats to the Peace, Breaches of the Peace, and Acts of Aggression," Charter of the United Nations, http://www.un.org/en/documents/charter/chapter7. shtml (accessed 7 July 2011).

26. Convention on the Prevention and Punishment of the Crime of Genocide, 9 December 1948, 78 U.N.T.S. 277, Article I, http://www.preventgenocide.org/law/convention/text.htm (accessed 7 July 2011) [UNCG].

27. Michael Barnett, Eyewitness to a Genocide: The United Nations and Rwanda (Ithaca: Cornell University Press, 2002).

28. Murder, extermination, enslavement, deportation, or forcible transfer of population; imprisonment or other severe deprivation of physical liberty in violation of fundamental rules of international law; torture; rape, sexual slavery, enforced prostitution, forced pregnancy, enforced sterilization, or any other form of sexual violence of comparable gravity; persecution against any identifiable group or collectivity on political, racial, national, ethnic, cultural, religious, gender as defined..., or other grounds that are universally recognized as impermissible under international law....; enforced disappearance of persons; the crime of apartheid; and other inhumane acts of a similar character intentionally causing great suffering, or serious injury to body or to mental or physical health.

29. Washington University School of Law, Whitney R. Harris World Law Institute, Crimes Against Humanity Initiative, Proposed International Convention on the Prevention and Punishment of Crimes Against Humanity, 2010, http://law.wustl.edu/harris/cah/docs/ EnglishTreatyFinal.pdf (accessed 3 August 2011).

30. Crimes Against Humanity Initiative, Proposed International Convention on the Prevention and Punishment of Crimes Against Humanity. Article 2 (Object and Purposes of the Present Convention) reads, in part: "1. The States Parties to the present Convention undertake to prevent crimes against humanity and to investigate, prosecute, and punish those responsible for such crimes," and 2. "To these ends, each State Party agrees: (a) To cooperate, pursuant to the provisions of the present Convention, with other States Parties to prevent crimes against humanity; and (b) To investigate, prosecute and punish persons responsible for crimes against humanity fairly and effectively."

31. For the UNCG's definition of "genocide," see UNCG, Article II, http://www.preventgenocide. org/law/convention/text.htm (accessed 3 August 2011). William Schabas writes: "Once crimes against humanity had been cured of its great shortcoming, the link with armed conflict, it quickly occupied the territory that had been reserved for genocide since 1948, namely attacks on minorities committed during peacetime. Moreover, crimes against humanity also adequately covered all those atrocities that lie on the fringes of 'pure' genocide, such as ethnic cleansing. Thus, nobody saw any practical need for reform, and the Rome Conference's confirmation of the enduring nature of the 1948 genocide definition was little more than perfunctory. History helpfully explains why the distinction between genocide and crimes against humanity was once so important, and why it is no longer so." See Schabas, "Genocide and the International Court of Justice: Finally, a Duty to Prevent the Crimes of Crimes," Genocide Studies and Prevention 2, no. 2 (2007): 101-22, 117.

32. On a different but related note, during the perpetration of atrocity crimes various officials (be they members of the Permanent Five, presidents, prime ministers, or others) have often seemed to suggest, nonsensically, that crimes against humanity are not as horrific as genocide. This, indeed, was the case during the early weeks and months of the 1994 Rwandan Genocide and the early years of the Darfur Genocide.

33. Issues include everything from the strengths and weaknesses of the decisions and judgments at the International Criminal Tribunal for the Former Yugoslavia (ICTY) and International Criminal Tribunal for Rwanda (ICTR) to distinctions between knowledgebased and legal-based interpretations of genocide; from the strengths and weaknesses of UN missions in atrocity zones to the pros and cons of charging individuals with genocide 
and crimes against humanity while a conflict is ongoing; and from the strengths and weaknesses of so-called safe corridors and safe areas to the impact of climate change on conflict and mass violence.

34. See Alison Des Forges, Leave None to Tell the Story: Genocide in Rwanda (New York: Human Rights Watch, 1999).

35. During the early days of the 1994 genocide in Rwanda there was genuine confusion among various actors in regard to what was taking place. For example, the UN Assistance Mission for Rwanda (UNAMIR) initially thought a coup d'état was under way, some pundits claimed that a civil war had broken out, while others initially claimed that it was an outbreak of violence among antagonists who had a long history of feuding as far back as the pre-colonial period, and some expatriates who had been working and living in Rwanda for years thought it was the outbreak of chaotic killing by extremists. Both the US government and the United Nations, though, had received ample information cum warnings that crimes against humanity and possibly genocide were under way.

36. A scholar on the ground generally has ready and ongoing access to individuals who are often quite willing to speak at length about the local culture, the personalities and motives of key actors, the ins and outs of local and regional politics, antecedents to the conflict, how the conflict evolved over time, and even plans for the future. Furthermore, being on the ground provides a scholar with the means to seek different perspectives; to monitor daily, if not hourly, incidents (rallies and protests, violent events, movement of troops and weapons); seek statements and warnings (rumors, declarations by politicians, bulletins posted on walls, memoranda intercepted by rebel forces, etc.); and observe concerns (e.g., fears of the locals). Informal conversations are often as instructive and informative as formal meetings.

Not even taking into account what one can ascertain from the locals, the views and insights of NGO personnel (particularly those who have been in country for years and are often responsible for writing weekly reports about the status of the country and region in which they are working, the concerns of the locals, the concerns and positions of local and regional politicians, speeches given by government officials, statements in the press, and even rumors afloat) are frequently invaluable.

37. Bill Clinton, quoted on Frontline (\#1710), “The Triumph of Evil" produced by Mike Robinson and Ben Loeterman, reported by Steve Bradshaw (25 January 1999), www.pbs.org/wgbh/pages/frontline/shows/evil (accessed 24 August 2011).

38. Short of researchers remaining or heading into an area that is explosive, researchers outside the area of conflict who have contacts in the region of conflict can request updates and then pass them on to the international media, human rights organizations, government officials, genocide scholars, and others. In other words, such individuals can serve as relay persons in getting the information out to the larger world. This, in fact, is the exact role I played during the first six weeks of the outbreak of violence in the Nuba Mountains during the summer of 2011. See, e.g., Samuel Totten, "Fear Pervades the Nuba Mountains that Sudan Government Intent on Genocide," Armenian Weekly, 11 June 2011, http://www.armenianweekly.com/2011/06/11/fear-pervades-nuba-mountains/; Samuel Totten, "Is Omar Hassan al-Bashir Up to Genocide Again?" On the Ground (Nicholas Kristoff's Blog), New York Times, 18 June 2011, http://kristof.blogs.nytimes. com/2011/06/18/is-omar-hassan-al-bashir-up-to-genocide-again/; Samuel Totten, "Cold Blooded Mass Murder," Sudan Tribune, 3 July 2011, http://www.sudantribune.com/ Cold-blooded-mass-murder-in-the,39420; and Samuel Totten, "Open Letter to Francis Deng: Now Is the Time to Prevent Genocide in the Nuba Mountains," South Sudan News Agency, 13 July 2011, http://www.southsudannewsagency.com/opinion/columnists/ open-letter-to-francis-deng. Also see Nicholas D. Kristof, "Yet Again in Sudan?" New York Times, 29 June 2011, www.nytimes.com/2011/06/30/opinion/30kristof.html; Jason Straziuso, "Satellite Evidence Indicates Mass Graves in Sudan," The Guardian, 14 July 2011, www.guardian.co.uk/world/feedarticle/9744377; and Geoff Hill, "Human Rights Activists Warn of Genocide in Sudan," Washington Times, 12 July 2011, http://www. washingtontimes.com/news/2011/jul/12/rights-activists-warn-of-genocide-in-sudan/?page=all. 
39. By sheer coincidence, some two weeks after this article was submitted to the University of Toronto Press, I was contacted by an organization called Our Humanity in the Balance and invited to become a board member. Its mission statement reads as follows: "Our Humanity in the Balance is an international group of volunteers developing innovative strategies to protect civilian populations in conflict areas, beginning in Darfur. We also intend to partner, where and when possible, with community groups in those areas to leverage our efforts." Its "motto" is: "We will go where we need to go to protect civilians in conflict zones and to prevent genocide." After checking out the organization's Web site and communicating via e-mail with three of the leaders of the organization, I readily and heartily chose to accept the invitation. Our Humanity in the Balance, http://www. ourhumanityinthebalance.org/ (accessed 19 October 2011).

40. Henry Huttenbach, "Can Genocide Be Prevented? No! Yes? Perhaps," Journal of Genocide Research 7, no. 3 (2005): 307-8.

41. The Bulletin of the Atomic Scientists was established in 1945 by scientists, engineers, and other experts who had created the atomic bomb as part of the Manhattan Project. "They knew about the horrible effects of these new weapons and devoted themselves to warning the public about the consequences of using them. Those early scientists also worried about military secrecy, fearing that leaders might draw their countries into increasingly dangerous nuclear confrontations without the full consent of their citizens. The Bulletin of the Atomic Scientists informs the public about threats to the survival and development of humanity from nuclear weapons, climate change, and emerging technologies in the life sciences. Through an award-winning magazine, our online presence, and the Doomsday Clock, we reach policy leaders and audiences around the world with information and analysis about efforts to address the dangers and prevent catastrophe." See Bulletin of Atomic Scientists Website, www.thebulletin.org/ (accessed 27 June 2011).

42. Past board members include, for example, Albert Einstein, 1921 Nobel Laureate in Physics; James Franck, 1925 Nobel Laureate in Physics; I.I. Rabi, 1944 Nobel Laureate in Physics; Linus Pauling, 1954 Nobel Laureate in Chemistry; Hans Bethe, 1967 Nobel Laureate in Physics; and W.K.H. Panofsky, Director Emeritus of the Stanford Linear Accelerator Center. Current board members include, among others, Freeman Dyson, 1984 Nobel Laureate; Richard Garwin, Philip D. Reed Senior Fellow for Science and Technology at the Council on Foreign Relations, New York; Marvin Goldberger, President Emeritus at the California Institute of Technology; John Polanyi, 1986 Nobel Laureate in Chemistry; Frank von Hippel, Co-director of the Program on Science and Global Security at Princeton University's Woodrow Wilson School of Public and International Affairs; and Steven Weinberg, 1979 Nobel Laureate in Physics. 